\section{ECONOMIA INDUSTRIAL}

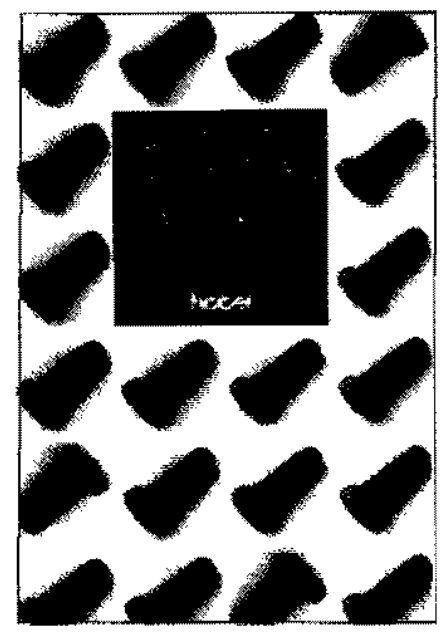

de ANITA KON

São Paulo: Nobel, 1994, 212 p.

por Ricardo Ernesto Vasquez Beltróo, Sociólogo pela FFLCH/USP e Mestrando em Administraçăo Pública na EAESP/FGV.

$\mathbf{F}$ rente à inegável importância da temática nas ciências econômicas, parecia injustificável a ausência, na produçẫo acadêmica brasileira, de uma obra que abordasse os principais tópicos da economia industrial. Essa lacuna veio a ser recentemente preenchida pelo livro de Anita Kon. Foi na experiência adquirida nas salas de aula da EAESP / FGV e da PUC/ SP, onde ministra a disciplina Economia Industrial nos niveis de graduaçăo e pós, que a autora, doutora em economia pela FEA/USP, percebeu a necessidade de trabalhar didaticamente os conceitos básicos dessa área teórica, procurando então fornecer ao leitor pesquisador o instrumental analítico imprescindível à inserçẫo na discussâo da temática aí envolvida.

A economia industrial vem se consolidando, nas últimas décadas, como um ramo específico da microeconomia, ganhando importância crescente em face das rápidas transformaçōes pelas quais vem passando a economia mundial, sobretudo no contexto de alta competitividade e globalização da produção e dos mercados neste final de milênio. As teorias pósmarginalistas evidenciaram a pouca aplicabilidade prática do instrumental analítico herdado da microeconomia tradicional para o entendimento dos fenômenos econômicos contemporâneos.
Guardadas as devidas proporçôes, podemos dizer que, dos fisiocratas aos marginalistas, a lógica de funcionamento do mercado sempre foi demonstrada a partir de modelos interpretativos que traziam em seu bojo a idéia de concorrência perfeita em contraposiçăo à de monopólio, e que explicavam o equalibrio das firmas e mercados, o comportamento dos preços, as decisões dos agentes etc. Oriunda da chamada escola inglesa, essa concepção vale-se do método dedutivo, que, partindo de modelos teóricos gerais, abstrai o funcionamento dos mercados (construindo complexas fórmulas matemáticas), admitindo como pressuposto básico que estes são regidos por uma lógica própria na qual a compra é determinada quase exclusivamente pelo preço de oferta, praticamente inexistindo variáveis outras que influenciem a inserção dos produtos.

Já a teoria da economia industrial fundamenta-se largamente nas críticas à abordagem do equilíbrio, $\mathrm{e}$, ao contrário dos marginalistas ou neoclássicos, valese do método indutivo, baseando-se no conhecimento empírico da realidade. Partindo da constatação da existência de um mercado amplamente oligopolizado (onde imperam fortes barreiras à inserçäo de novos competidores), e da observação tanto das condições institucionais em que operam as firmas quanto das transformações organizacionais a elas impostas pelos mais variados tatores (como, por exemplo, os avanços tecnológicos), os pós-marginalistas entendem que são muitas as dimensôes que pesam significativamente nas decisỏes e comportamento das firmas. Assim, o princípio da maximizaçăo dos lucros perde poder explicativo, sobretudo em um contexto histórico de crescente grau de complexidade dos processos de produçâo e distribuiçăo, ganhando maior relevância, entre outros, fatores como os limites e as possibilidades de crescimento dos mercados, os determinantes de investimento e os modos de financiamento disponiveis.

No primeiro capítulo, Anita Kon discute as mais importantes idéias oriundas das diferentes escolas do pensamento econômico, especificando os contextos próprios em que emergiram e ganharam relevância, e apontando as principais criticas a elas dirigidas, mostrando em que medida influenciaram as abordagens mais recentes do comportamento das firmas capitalistas. Nos cinco capítulos seguintes, essa discussão é aprofundada, mas sempre com ênfase em temas específicos e centrais da teoria da economia industrial, entre os quais podemos enumerar: a formaçảo de preços e as curvas de demanda no oligopólio; 
os processos de acumulação, concentração e centralização do capital; a ocorrência dos cartéis, trustes e fusōes; o crescimento das empresas e os impactos sofridos no interior do seu próprio arcabouço organizacional e comportamental; as estratégias de conquista de mercados, tais como a diferenciaçăo do produto, o esforço de venda, a diversificação da produção; a terceirização; e ainda a internacionalização do capital. A autora sintetiza aí as principais conclusões a que chegou Michalet em importante estudo sobre as multinacionais ${ }^{1}$, e mostra que esse processo anda de mãos dadas com o fenômeno da globalização ${ }^{2}$.

Do sétimo capítulo em diante, a autora aborda temas complementares, sempre presentes na discussão da realidade atual e dos desafios relacionados ao desenvolvimento da indústria, tais como o desenvolvimento tecnológico (novos processos produtivos, realocação de recursos, automação etc.); os recursos humanos e a suas implicações na estrutura ocupacional; as variáveis presentes nas decisões acerca da localização para a instalação de indústrias, e os impactos delas decorrentes; e finalmente as políticas públicas (instrumentos de política industrial, regulação e desregulação, e privatização de empresas públicas). Além disso, nos capítulos 8 e 10 encontramos apêndices que abordam o caso brasileiro, em que a autora avalia as recentes transformaçóes observadas em nossa realidade no que diz respeito à distribuição espacial e setorial da mão-de-obra, e apresenta uma breve análise, sob a perspectiva histórica, da política pública industrial no Brasil, sobretudo após a Segunda Guerra Mundial.

Dados os objetivos do livro, há uma grande preocupação com a didática na estruturação do texto. Em primeiro lugar, porque os seus dez capítulos estão encadeados numa seqüência que permite ao leitor situar-se no cenário das discussões mais atuais a respeito do tema. Assim, a autora parte da contextualização histórica da qual a temática emerge e ganha corpo, no seio das teorias econômicas, aborda os aspectos conceituais básicos para o domínio das questôes relacionadas à economia industrial, enquanto paradigma analítico, e finalmente discute as questóes que, contemporaneamente, estão no centro não apenas do debate acadêmico, mas na agenda dos responsáveis pela alocação espacial e setorial de recursos na produção industrial, seja no âmbito das empresạs ou na gestão das políticas públicas. As rápidas transformações ocorridas no setor, como o movimento de internacionalização do capital, a aceleração do ritmo de desenvolvimento tecnológico, a redefinição de es- tratégias de conquista e consolidação de mercados, e a evidente importância do investimento maciço no chamado capital humano, entre outras coisas, têm apontado para a necessidade de remodelação de todo o aparato produtivo. Assim, torna-se cada vez mais indispensável o domínio de um instrumental básico que subsidie as decisões, que evidentemente não podem prescindir de um conhecimento da lógica de operaçāo das macroestruturas na determinação dos movimentos do capital, sobretudo num cenário de economia globalizada, oligopolizada e, por mais paradoxal que possa parecer, de acirramento da concorrência.

Em segundo lugar, a preocupação com a didática revela-se na utilizaçăo de uma linguagem acessível a alunos de graduação e profissionais de todas as áreas de formação, inclusive os não-iniciados no apavorante "economês", sem que isso signifique subestimar a inteligência dos leitores, procedimento infelizmente muito comum em tentativas do gênero. Para os que pretendem avançar no conhecimento das questōes abordadas, há indicaçōes bibliográficas ao final de cada capítulo.

Por fim, é importante frisar que a autora parece ter encontrado o difícil ponto de equilíbrio na apresentação de uma temática ainda pouco explorada na produçāo brasileira, uma vez que, sem pretender trilhar o caminho do aprofundamento de discussōes teóricas muito específicas, conseguiu evitar o seu oposto, ou seja, a produção dos tão comuns e entediantes manuais de introdução a temas ou campos do conhecimento que, em vez de despertar, tendem a ofuscar $o$ interesse mesmo do mais paciente leitor.

1. MICHALET, C.A. O capitalismo mundial. São Paulo: Paz e Terra, 1984. Nessa obra, o autor estabelece uma tipologia das multinacionais no que diz respeito ao seu formato organizacional, distinguindo trés fases sucessivas na sua forma de evolução, identificando as fontes de financiamento de que se valem e, mais importante, identificando os motivos de peso mais significativo nas decisōes acerca de investimento dessas empresas em países estrangeiros.

2. Segundo a autora, a "transnacionalização das economias, através das empresas multinacionais, corresponde a uma nova dinâmica do sistema econômico mundial, e a análise dessa dinâmica é centrada no estudo das decisōes da firma, observada particularmente com os instrumentos da microeconomia, procurando entender os fatores explicativos da decisâo empresarial de criar filiais de produção no estrangeiro" (p. 109-10). 